\title{
Origin, clonal diversity, and evolution of the parthenogenetic lizard Darevskia unisexualis
}

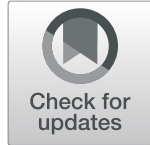

Andrey A. Vergun 1,2, Anastasiya E. Girnyk', Vitaly I. Korchagin', Seraphima K. Semyenova', Marine S. Arakelyan", Felix D. Danielyan ${ }^{3}$, Robert W. Murphy ${ }^{4}$ and Alexey P. Ryskov ${ }^{1 *}$ (i)

\begin{abstract}
Background: The hybridization of female D. raddei and male D. valentini gave rise to the parthenogenetic Caucasian rock lizard Darevskia unisexualis. A previously identified genetic polymorphism in the species consisted of one common and two allozyme clones. Analysis of microsatellites and single nucleotide polymorphisms (SNPs) from the three species yields estimates of clonal diversity and tests the hypothesis of a single origin for $D$. unisexualis.

Results: Genotyping and sequencing of four microsatellite-containing loci for 109 specimens of D. unisexualis, 17 D. valentini, and 45 D. raddei nairensis identified 12 presumptive clones, including one widespread and 11 rare clones. Most individuals in some localities had a rare clone. Clone-specific alleles in D. unisexualis were compared with those of the parental species. The results inferred a single hybridization event. Post-formation mutations best explain the less common clones.

Conclusions: Interspecific analyses identify alleles inherited by D. unisexualis from its bisexual ancestors. SNP analyses fail to reject the hypothesis of a single interspecific origin of $D$. unisexualis, followed by microsatellite mutations in this initial clone. Microsatellites detect higher clonal diversity in D. unisexualis compared to allozymes and identify the likely origins of clones. Our approach may be applicable to other unisexual species whose origins involve interspecific hybridization.
\end{abstract}

Keywords: Darevskia, Lizards, Parthenogenesis, Clones, Clonal variation, Hybridization, Microsatellites, SNP markers, Mutations

\section{Background}

Species of all-female, unisexual vertebrates reproduce without fertilization. Being clones, parthenospecies' daughters are identical to their mothers, with rare exception. They are very rare in nature and usually arise via hybridization [1-5]. Some species of squamate reptiles reproduce clonally via parthenogenesis [6-8]. In some cases, the formation of parthenospecies is constrained phylogenetically [9], but in other cases not [10]. Among vertebrates, parthenogenesis was first described in the lizard genus Darevskia (Lacertidae) [11]. Parthenogenesis in lizards has received considerable attention, including how genetic

\footnotetext{
* Correspondence: ryskov@mail.ru

'Laboratory of Genome Organization, Institute of Gene Biology of the Russian Academy of Sciences, Vavilova Str., 34/5, Moscow 119334, Russia Full list of author information is available at the end of the article
}

and ecological factors play upon natural selection and speciation via hybridization, as well as the generation and evolution of genetic diversity [2, 12-16]. Hybrid parthenospecies possess the genetic diversity of their parental species $[9,10,14]$ and most parthenospecies are triploids, although diploids exist, and their fixed heterozygosity results in high levels of nuclear gene diversity [17]. Sister chromatid pairing maintains heterozygosity in clones; this may offset potential reduced fitness [18, 19], but can also lead to heterozygote disadvantage and negative epistasis.

Most parthenospecies have several clones owing to mutations (especially in hypervariable microsatellite loci), multiple hybridizations from different founders, or rarely some level of genetic recombination or new hybridization events [20-22]. This variation correlates with time since

(C) The Author(s). 2020 Open Access This article is licensed under a Creative Commons Attribution 4.0 International License, which permits use, sharing, adaptation, distribution and reproduction in any medium or format, as long as you give appropriate credit to the original author(s) and the source, provide a link to the Creative Commons licence, and indicate if changes were made. The images or other third party material in this article are included in the article's Creative Commons licence, unless indicated otherwise in a credit line to the material. If material is not included in the article's Creative Commons licence and your intended use is not permitted by statutory regulation or exceeds the permitted use, you will need to obtain permission directly from the copyright holder. To view a copy of this licence, visit http://creativecommons.org/licenses/by/4.0/ The Creative Commons Public Domain Dedication waiver (http://creativecommons.org/publicdomain/zero/1.0/) applies to the data made available in this article, unless otherwise stated in a credit line to the data. 
hybridization, size of the area the ancestral species occupied, and ecological conditions [23-25].

Herein, we use parthenogenetic Darevskia unisexualis to test three hypotheses. 1) The parthenospecies has a single origin from the hybridization of paternal $D$. valentini and maternal D. raddei [26]. 2) Most clonal variation owes to post-hybridization mutation. And 3) analyses microsatellite loci will detect higher clonal diversity compared to allozymes. To test these hypotheses, assessments of clonal variation are essential. The extent of variation within parthenospecies can depend on the rate of clonal formation [27], ecological specialization of clonal lineages [28], historical biogeography [29], and other processes.

Parthenogenetic D. unisexualis was found to have three allozyme clones, based on analyses of 36 loci from three populations of $D$. unisexualis in central Armenia $(n=57)$ [26]. Rare clones occurred in two individuals and all others consisted of a common, widespread clone. Its low level of variation in mitochondrial DNA and allozymes among populations suggested that the founders of D. unisexualis involved very few individuals $[25,26]$. However, the origin of this variation, whether owing to point mutations, insertion/deletions, multiple origins, or more complex genomic reorganization, remains unresolved, in part due to the species' widespread distribution. The species occurs in East Anatolia and in small, isolated areas in central Armenia (Aragatsotn, Gegharkunik, Kotayk, Lori, and Shirak provinces) [30] where it prefers rocky exposures and its vertical distribution ranges from 1500 to $2300 \mathrm{~m}$ a.s.l. Although many populations are large, some are threatened by overgrazing and urbanization. Accordingly, this species is classified as "Near Threatened" by the IUCN and listed as "Vulnerable" in the Red Book of Armenia [30].

Paternal D. valentini occurs in eastern Turkey and high montane habitats (elevations of $1900-3110 \mathrm{~m}$ ) in central Armenia and adjoining Georgia; populations are locally abundant and IUCN assessed this species as Least Concern [30]. Maternal ancestor D. raddei is widespread throughout central Armenia, with isolated populations in the north and in south-central portions of the country; it also occurs in adjoining Georgia and East Anatolia [31]. Like other congeners, D. raddei prefers stony or rocky habitats at elevations of 1000-2660 m. Individuals are usually abundant and the IUCN assessed it as "Least Concern" [30]. Darevskia raddei has been suggested to be a species-complex, containing the forms "raddei" and "nairensis" whose taxonomic status is still a matter of debate $[25,32,33]$, and this uncertainty extends into the origins of parthenogenetic clones [34]. Notwithstanding, $D$. raddei nairensis occurs sympatrically with $D$. unisexualis at Lchap, Armenia (Gegharkunic Province) on the western margin of Lake Sevan [30]. Because the parental species of $D$. unisexualis exhibit high allozyme variation among populations $[35,36]$, the parthenospecies likely originated from few parental individuals [25]. Analysis of mitochondrial DNA obtained a concordant result; the four populations of $D$. unisexualis had identical sequences, but populations of $D$. raddei exhibit variation [25].

Our analyses of $D$. unisexualis use variation at four microsatellite-containing loci in seven Armenian populations. The same methods were used previously in our assessments of D. dahli [37], D. rostombekowi [38], and D armeniaca [39]. Interspecies comparisons use alleles of homologous loci from $D$. unisexualis and bisexual parents $D$. valentini and $D$. raddei nairensis. Analyses of $D$. unisexualis and its maternal parent also include partial sequences of mitochondrial cytochrome b $(C Y T B)$. Results show that $D$. unisexualis has a level of clonal diversity similar to ones of other parthenospecies of Darevskia. Analyses provide direct information about interspecific hybridization founder events, and about possible mutations in the initial hybrid clones.

\section{Results}

All individuals of $D$. unisexualis had identical fragments of CYTB. The fragment assigned to haplotype of $D$. raddei nairensis from Lchashen, Armenia (data not shown; GenBank Accession No. U88613).

Each microsatellite locus in individuals of $D$. unisexualis had two alleles. Both length and structure of the alleles differed within individuals. Further, the flanking regions of the alleles had single nucleotide polymorphisms (SNPs) in fixed positions (Fig. 1 and Table S1). All clones had identical combinations of parent-specific SNPs for all loci, which was consistent with an origin from a single interspecies hybridization event; these results did not reject the first hypothesis that a single hybridization event gave rise to $D$. unisexualis. Further, the alternative hypothesis of multiple origins was rejected because $D$. unisexualis did not share alleles with multiple variants of either parental species. Assuming this to be true, then we could not reject the second hypothesis that most clonal variation owed to posthybridization mutation.

Microsatellite analyses detected greater variation than reported for allozymes [26]. Loci Du215(uni) (D. unisexualis) and Du47G(uni) had three alleles, Du281(uni) had six, and Du323(uni) had two alleles (Table S1). In the paternal parent, Du215(val) (D. valentini) was homozygotic, as was Du47G(rad) (D. raddei nairensis) in the maternal parent. Du281(val) had five alleles, Du323(val) had six, Du47G(val) had 10, Du215(rad) had two, Du281(rad) had 11, and Du323(rad) had two. Alleles in parental $D$. valentini and $D . r$. nairensis contained microsatellite clusters and the flanking regions had SNPs 


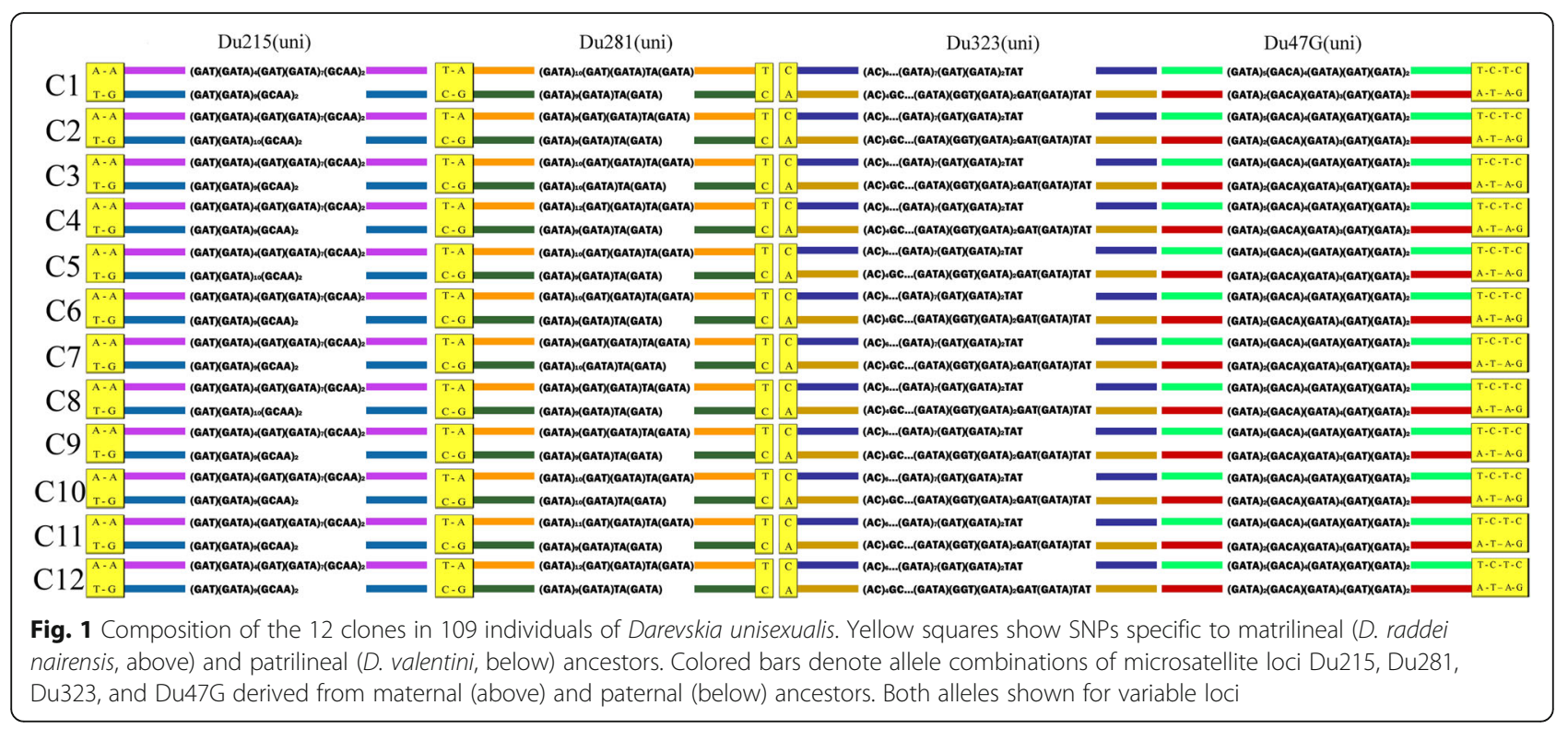

at fixed positions. Six of the 14 alleles in D. unisexualis matched perfectly to parental alleles. Alleles Du215(uni)2, 3 and Du47G(uni)1 differed from their parental species in their flanking region SNPs, and Du215(uni)2,3 differed in microsatellite repeat structure. The absence of these alleles in the parental species may have owed to sampling artifacts or genetic recombination in D. unisexualis.

Variation in SNPs and microsatellites resulted in 12 clones (Fig. 1 and Table 1). Clone $\mathrm{C} 1$ (clone 1) was found in all populations and it occurred in 37 individuals (33.9\% total cohort). All other clones occurred in one or two populations only. Clone C2 occurred only at Artavaz $(n=28$; $25.7 \%$ total cohort), $\mathrm{C} 4$ at Noratus only ( $n=14 ; 12.8 \%$ total cohort), and C3 dominated at Lchap ( $\mathrm{n}=14 ; 12.8 \%$ of total cohort). Clones C5-C12 occurred in one or two populations and were found in $1-3$ individuals $(n=16$; $14.6 \%$ total cohort). Clones C10-C12 were represented by only one individual each. Because allozyme analyses only

Table 1 Clones, clone composition, sample size, distribution of clones among populations, and diversity of alleles in D. unisexualis. For clone composition, allelic notation is (allele number in D. nairensis + allele number in D. valentini). Alleles shown in Fig. 1

\begin{tabular}{|c|c|c|c|c|c|c|c|c|c|}
\hline \multirow[t]{2}{*}{ Clone } & \multirow[t]{2}{*}{ Clone composition } & \multicolumn{7}{|c|}{ Population } & \multirow{2}{*}{$\begin{array}{l}\text { Number of } \\
\text { individuals } \\
\text { (clone } \\
\text { frequency) }\end{array}$} \\
\hline & & Artavaz & Hrazdan & Kuchak & Lchap & Noratus & Sevan & Tsovak & \\
\hline $\mathrm{C1}$ & $\operatorname{Du} 215(1+3)+\operatorname{Du} 281(3+6)+\operatorname{Du} 323(1+2)+\operatorname{Du} 47 G(1+3)$ & 1 & 4 & 4 & 2 & 1 & 2 & 23 & $37(0.339)$ \\
\hline C2 & $\operatorname{Du} 215(1+2)+\operatorname{Du} 281(5+6)+\operatorname{Du} 323(1+2)+\operatorname{Du} 47 G(1+3)$ & 28 & 0 & 0 & 0 & 0 & 0 & 0 & $28(0.257)$ \\
\hline C3 & $\operatorname{Du} 215(1+3)+\operatorname{Du} 281(3+4)+\operatorname{Du} 323(1+2)+\operatorname{Du} 47 G(1+3)$ & 0 & 0 & 4 & 10 & 0 & 0 & 0 & $14(0.128)$ \\
\hline C4 & $\operatorname{Du} 215(1+3)+\operatorname{Du} 281(1+6)+\operatorname{Du} 323(1+2)+\operatorname{Du} 47 G(1+3)$ & 0 & 0 & 0 & 0 & 14 & 0 & 0 & $14(0.128)$ \\
\hline C5 & $\operatorname{Du} 215(1+2)+\operatorname{Du} 281(3+6)+\operatorname{Du} 323(1+2)+\operatorname{Du} 47 G(1+3)$ & 3 & 0 & 0 & 0 & 0 & 1 & 0 & $4(0.037)$ \\
\hline C6 & $\operatorname{Du} 215(1+3)+\operatorname{Du} 281(3+6)+\operatorname{Du} 323(1+2)+\operatorname{Du} 47 G(1+2)$ & 0 & 0 & 0 & 1 & 0 & 0 & 2 & $3(0.027)$ \\
\hline C7 & $\operatorname{Du} 215(1+3)+\operatorname{Du} 281(4+5)+\operatorname{Du} 323(1+2)+\operatorname{Du} 47 G(1+3)$ & 0 & 0 & 2 & 0 & 0 & 0 & 0 & $2(0.018)$ \\
\hline C8 & $\operatorname{Du} 215(1+2)+\operatorname{Du} 281(5+6)+\operatorname{Du} 323(1+2)+\operatorname{Du} 47 G(1+2)$ & 2 & 0 & 0 & 0 & 0 & 0 & 0 & $2(0.018)$ \\
\hline C9 & $\operatorname{Du} 215(1+3)+\operatorname{Du} 281(5+6)+\operatorname{Du} 323(1+2)+\operatorname{Du} 47 G(1+3)$ & 0 & 1 & 1 & 0 & 0 & 0 & 0 & $2(0.018)$ \\
\hline $\mathrm{C} 10$ & $\operatorname{Du} 215(1+3)+\operatorname{Du} 281(3+4)+\operatorname{Du} 323(1+2)+\operatorname{Du} 47 G(1+2)$ & 0 & 0 & 1 & 0 & 0 & 0 & 0 & $1(0.009)$ \\
\hline C11 & $\operatorname{Du} 215(1+3)+\operatorname{Du} 281(2+6)+\operatorname{Du} 323(1+2)+\operatorname{Du} 47 G(1+3)$ & 0 & 0 & 0 & 0 & 1 & 0 & 0 & $1(0.009)$ \\
\hline $\mathrm{C} 12$ & $\operatorname{Du} 215(1+3)+\operatorname{Du} 281(1+6)+\operatorname{Du} 323(1+2)+\operatorname{Du} 47 G(1+2)$ & 0 & 0 & 0 & 0 & 1 & 0 & 0 & $1(0.009)$ \\
\hline \multicolumn{2}{|c|}{ Total number of individuals } & 34 & 5 & 12 & 13 & 17 & 3 & 25 & 109 \\
\hline \multicolumn{2}{|c|}{$\begin{array}{l}\text { Total number of clones } \\
\text { Clone diversity (\%) }\end{array}$} & $\begin{array}{l}4 \\
(11.8)\end{array}$ & $\begin{array}{l}2 \\
(40.0)\end{array}$ & $\begin{array}{l}5 \\
(41.7)\end{array}$ & $\begin{array}{l}3 \\
(23.1)\end{array}$ & $\begin{array}{l}4 \\
(23.5)\end{array}$ & $\begin{array}{l}2 \\
(66.7)\end{array}$ & $\begin{array}{l}2 \\
(8.0)\end{array}$ & 12 \\
\hline
\end{tabular}


resolved three clones, our microsatellite results failed to reject the third hypothesis that microsatellites will detect more clones than allozymes.

The average values of allelic richness for individual loci varied significantly within the species. Locus Du47G had one allelic variant in all populations of $D$. raddei nairensis (Table S2), as did Du215 in D. valentini (Table S3). However, the polymorphic loci of the parental species often had greater allelic richness than $D$. unisexualis. Allelic richness of Du281 in populations of $D$. raddei nairensis $(6.01 \pm 0.24)$ was significantly higher $(p<0.05)$ than in $D$. unisexualis $(2.42 \pm 0.17)$, as was allelic richness of Du47G (3.36 \pm 0.24$)$ in $D$.valentini versus $D$. unisexualis $(2.10 \pm 0.04)(\mathrm{p}<0.05)$. Nevertheless, the average values of total allelic richness of all loci did not differ significantly among all species $(p>0.05)$ due to homozygosity of some loci of the parental species.

The TCS network placed the most common clone (C1) in a central location with respect to the other, less common clones. The other clones differed from it by one or two mutations only (Fig. 2). Within populations, clonal diversity in D. unisexualis ranged from 8.0 to $66.7 \%$ (Table 1). The highest levels were observed at Sevan, which had two clones in three individuals, and at Kuchak, in which the 12 individuals had one common and four rare clones. With two clones in 25 individuals, Tsovak had the lowest level of genotypic diversity. The number of alleles varied from 2 to 4 and allelic richness ranged from 1.98 to 3.00 (Table 2). Tsovak (Du281 and Du47G), Hrazdan (Du215 and Du323), and Kuchak (Du323 and Du281) had the highest values of allelic richness.

Population genetic indices for four populations of $D$. raddei nairensis (42 individuals) were given in Table S2. Populations Ayrivank $(n=2)$ and Bjni $(n=1)$ were excluded from analyses owing to small sample sizes. Observed heterozygosity ranged from 0.40 to 1.00 (average 0.60-1.00 depending on locus), and this was similar to expected heterozygosity, which ranged from 0.32 to 0.83 (average 0.32-0.80 depending on locus). From 1 to 10 alleles were observed, depending on locus and population. Depending on locus and population, allelic richness varied from 1 to 6.67. Du281 at Pyunik had highest value of allelic richness. Expected heterozygosity was greatest in Lchashen (Du281). Population genetic indices for $D$. valentini (17 individuals) were calculated previously [39] and are presented in the Table S3.

\section{Discussion}

Within D. unisexualis, the two rare allozyme clones were hypothesized to have resulted via post-formation mutation of the preexisting common clone [26]. This

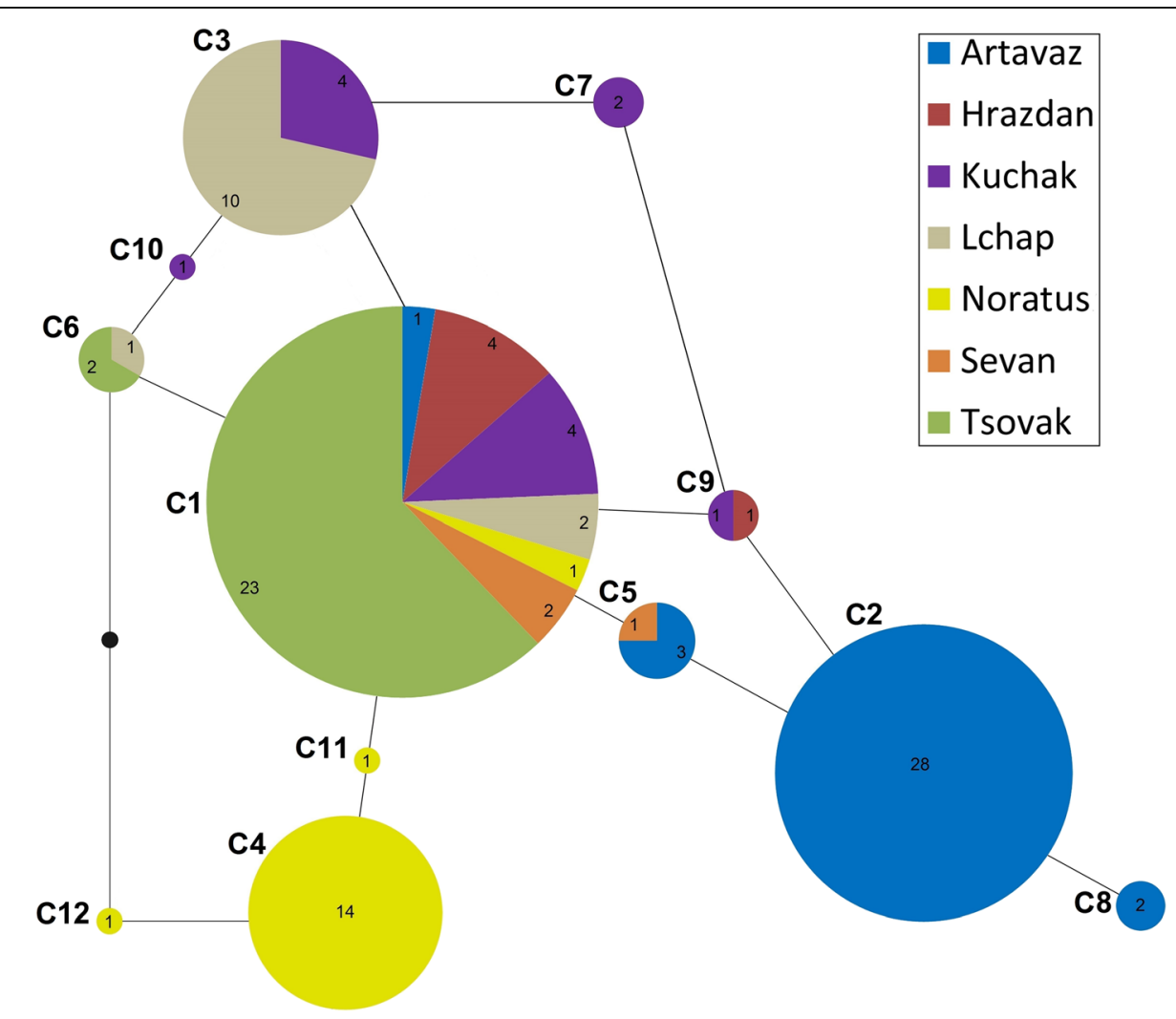

Fig. 2 A statistical parsimony (TCS) network showing the geographic associations of the 12 clones in parthenogenetic Darevskia unisexualis. Analyses used differences in the number of repeats, but not indels. Number of individuals in populations given in pie slices 
Table 2 Microsatellite diversity for seven populations of $D$. unisexualis

\begin{tabular}{|c|c|c|c|}
\hline Locus & Population & Alleles (N) & $R_{S}$ \\
\hline \multirow[t]{9}{*}{ Du215 } & Lchap & 2 & 2.06 \\
\hline & Kuchak & 2 & 2.00 \\
\hline & Tsovak & 2 & 1.99 \\
\hline & Noratus & 2 & 1.99 \\
\hline & Artavaz & 3 & 1.98 \\
\hline & Hrazdan & 2 & 3.00 \\
\hline & Sevan & 3 & 1.98 \\
\hline & Total & 3 & 3.00 \\
\hline & Mean \pm SE & $2.29 \pm 0.18$ & $2.14 \pm 0.14$ \\
\hline \multirow[t]{9}{*}{ Du281 } & Lchap & 3 & 2.28 \\
\hline & Kuchak & 4 & 2.60 \\
\hline & Tsovak & 2 & 3.27 \\
\hline & Noratus & 4 & 2.52 \\
\hline & Artavaz & 3 & 2.32 \\
\hline & Hrazdan & 3 & 2.00 \\
\hline & Sevan & 2 & 1.98 \\
\hline & Total & 6 & 6.00 \\
\hline & Mean \pm SE & $3 \pm 0.31$ & $2.42 \pm 0.17$ \\
\hline \multirow[t]{9}{*}{ Du323 } & Lchap & 2 & 1.98 \\
\hline & Kuchak & 2 & 2.00 \\
\hline & Tsovak & 2 & 1.99 \\
\hline & Noratus & 2 & 1.99 \\
\hline & Artavaz & 2 & 1.98 \\
\hline & Hrazdan & 2 & 2.00 \\
\hline & Sevan & 2 & 1.98 \\
\hline & Total & 2 & 2.00 \\
\hline & Mean \pm SE & $2 \pm 0.00$ & $1.99 \pm 0.00$ \\
\hline \multirow[t]{9}{*}{ Du47G } & Lchap & 3 & 2.14 \\
\hline & Kuchak & 3 & 2.00 \\
\hline & Tsovak & 3 & 2.23 \\
\hline & Noratus & 3 & 2.21 \\
\hline & Artavaz & 3 & 2.15 \\
\hline & Hrazdan & 2 & 2.00 \\
\hline & Sevan & 2 & 2.20 \\
\hline & Total & 3 & 3.00 \\
\hline & Mean \pm SE & $2.71 \pm 0.18$ & $2.13 \pm 0.04$ \\
\hline
\end{tabular}

$N$ number of alleles, $R_{S}$ allelic richness

explanation is in accordance with Parker et al.'s model [24] that little allozyme and mtDNA variation exists in species having a single hybridization origin. Spatially, one widespread clone is common, but a few rare clones also exist. This pattern holds for other parthenogenetic Caucasian rock lizards $[40,41]$, as well as other parthenogenetic lizards [42]. Comparatively, parthenogenetic D. dahli and
D. armeniaca also have one common clone and several rare ones [40]. Only parthenogenetic $D$. rostombekowi exhibited a single allozyme clone [43]. The level of diversity in D. unisexualis was also similar to that found in parthenogenetic Aspidoscelis neomexicanus [44], which also has a hybrid origin. In contrast, parthenogenetic Heteronotia binoei was reported to have much higher variation [42].

Our microsatellites and SNPs reveal higher levels of clonal diversity in parthenospecies of Darevskia than allozymes did. Analyses involving 109 individuals of $D$. unisexualis from seven populations in Armenia identify 12 clones that differ in their frequencies and population distribution. Analyses of 35 allozyme loci in parthenogenetic $D$. dahli [40], D. rostombekowi [43], and D. armeniaca [45] resolved five, one, and four clones, respectively, while our genomic approach resolves 11 clones in D. dahli [37], five in D. rostombekowi [38], and 13 in D. armeniaca [39]. Thus, assessments of microsatellites discover more variation than allozymes.

Analyses cannot reject the hypothesis of one hybridization event [26] forming $D$. unisexualis due to identical SNPs in flanking regions of the microsatellite loci and a single mitochondrial haplotype. However, it remains possible that ancestral parents experienced back crossings. Clones $\mathrm{C} 1-\mathrm{C} 12$ differ from each other only by microsatellite sequences. Variation in lengths of microsatellite alleles surely owes to the high rate of indels, which can occur in one generation [46]. However, future analyses of additional populations of $D$. unisexualis can test for the possibility of multiple origins, which could account for geographic patterns of alleles, as opposed to mutations within geographic regions. It is particularly important to sample populations from geographically distant locations in Turkey to differentiate between scenarios of dispersal and multiple origins.

Our analyses detect high genotypic diversity in parthenogenetic $D$. unisexualis similar to those found in parthenogenetic $D$. dahli and $D$. armeniaca. Variation in clone frequency could result from independent origins of a unisexual species because of geographic variation in the ancestors. Clones such as $\mathrm{C} 2$ and $\mathrm{C} 4$ appear to be restricted to a single population, and C3 dominates in one population. Unique clones also dominate in some populations of parthenogenetic $D$. dahli [37] and D. armeniaca [39]. All populations have $\mathrm{C} 1$ and the other clones differ from it by one or two microsatellite repeats only. Thus, the presence of these clones is more likely due to postformation mutations [46], limited dispersal, and genetic drift. Owing to its widespread and ubiquitous distribution, C1 is likely ancestral in D. unisexualis (Table 1) [24]. All other clones have restricted geographic distributions.

Identification of the original area of hybridization can lead to insights and assessments of dispersal, especially 
when combined with dating and associated landscape models. Such analyses can lead to predictions about how climate change will affect the species. However, the exact region where $\mathrm{C} 1$ originated remains unknown. The highest values of clonal diversity occur in Sevan and Kuchak, and both populations are candidate sites for the origin of $\mathrm{C} 1$. Clones at Kuchak have origins via microsatellite mutations at Du281 and Du47G, while those at Sevan arose through mutation at Du215. Kuchak is also a contact zone of hybridization between $D$. unisexualis and $D$. valentini $[47,48]$. Notwithstanding, D. raddei nairensis occurs sympatrically with $D$. unisexualis on the western margin of Lake Sevan [30]. This suggests two scenarios for the origin of D. unisexualis. First, the initial $\mathrm{C} 1$ arose in the Kuchak region, and then these lizards dispersed eastwardly to other regions (Artavaz, Lchap, Noratus, and other populations). Alternatively, the population at Sevan may have dispersed to western and southern areas. The site of origin remains uncertain, especially since it was proposed to have occurred on the slopes of Mount Aragats [34].

Parthenospecies of Darevskia appear to have evolved recently [10]. Relative to the parental species, they exhibit great mtDNA similarity and low levels of intraspecific variation. Darevskia unisexualis may have originated about 5000 years ago [9], or along with other parthenospecies approximately 200,000-70,000 years ago [34]. Regardless, dispersal resulted in widespread distributions involving many ecological niches.

Because it is not possible to root the network with an outgroup, statistical parsimony network (Fig. 2) has no evolutionary direction. Accordingly, we cannot be certain about the identity the primitive allele. Further, the implied reticulation results in most alleles having equal likelihoods of association with others. These are not inconsequential concerns [49]. The only seemingly unquestionable association is $\mathrm{C} 8$ being derived from $\mathrm{C} 2$; most other associations remain possible. Regardless, the most widespread allele is consistent with $\mathrm{C} 1$ being ancestral.

In summary, microsatellite genotyping analyses [3739 , this study] suggest that clonal diversity in parthenogenetic $D$. unisexualis and D. rostombekowi, which originated via a single hybridization event, owes to mutations in the initial clones. Similarly, post-formation mutations add to diversity in D. dahli and D. armeniaca, both of which originated via a few hybridizations.

\section{Conclusion}

Analyses of four microsatellite loci and single nucleotide polymorphisms (SNPs) in their flanking regions reveal 12 presumptive clones in parthenogenetic $D$. unisexualis, including one widespread common and 11 rare clones. Assessments confirm that formation of the parthenospecies resulted from the hybridization of female $D$. raddei nairensis and male $D$. valentini. Several overall rare clones are numerous and dominate in some populations. Clonal diversity in $D$. unisexualis appears to result from microsatellite mutations in the initial clone. Parentspecific microsatellite and SNP markers identify multiple clones that allozymes could not. This approach should prove to be equally applicable to detailing the origin and variation of other unisexual species.

\section{Methods}

DNA samples were taken from seven populations of parthenogenetic $D$. unisexualis $(n=109)$. Analyses also included its parental species: six populations of matrilineal $D$. raddei nairensis $(n=45)$, and four populations of $D$. valentini $(n=17)$. All samples were from Armenia (Table 3 and Fig. 3).

We used the tips of tails of museum specimens in the herpetological collection of Yerevan State University, as well as a few blood samples collected in 2018 (Table 3). Yerevan State University approved all work with the lizards, which adhered strictly to ethical guidelines. Blood samples were obtained by removing tail tips, which autotomize, and the lizards were then released at the site of collection. DNA extraction used the standard phenol-chloroform method with proteinase $\mathrm{K}$, and resuspension in TE buffer, $\mathrm{pH}$ 8.0.

PCR-amplification of tetranucleotide microsatellite loci Du215, Du281, Du323, and Du47G used established primers $[37-39,50]$. The procedures for isolating and sequencing of individual allelic PCR-amplifications from polyacrylamide gels were carried out as described previously $[37,46]$.

A GenePak PCR Core Kit (Isogene) was used for amplifications in a $20 \mu \mathrm{l}$ reaction volume, which included approximately $50 \mathrm{ng}$ of DNA and $1 \mu \mathrm{M}$ of each primer. PCR amplification conditions were used as described previously [39]. Both allelic PCR products of a locus were visualized by electrophoresis in $8 \%$ native (nondenaturating) polyacrylamide gel and then excised, purified and sequenced in both directions as previously described [39].

The number of alleles (allelic richness, $R_{S}$ ) was adjusted for sample size. Expected heterozygosity was calculated by using an in-house $\mathrm{R}$ programming language script (available at https://github.com/andrewgull/PopGenScripts) employing packages Poppr and Mmod [51-53].

As before [54], a statistical parsimony haplotype network was calculated using TCS v.1.21 to visualize geographic distribution of clones and overall similarity. Notwithstanding, homologous alleles in parthenogenetic clones had linear arrangements via repeat number with little or no recombination. Thus, our coding (Table 4) considered gaps as a fifth state $[37,55]$.

We amplified and sequenced a $320 \mathrm{bp}$ fragment of mitochondrial $C Y T B$ for 17 specimens of $D$. unisexualis, which amounted to 2-3 individuals from each population, as 
Table 3 Species, populations, and samples of Darevskia used in this study

\begin{tabular}{|c|c|c|c|c|c|c|}
\hline Species & (Map no.) Population & Coordinates & $N$ tail tips & $N$ blood & $N_{\text {(locality) }}$ & $N_{\text {(species) }}$ \\
\hline \multirow[t]{7}{*}{ D. unisexualis } & (1) Artavaz (Hankavan) & $40.622278 \mathrm{~N} 44.580944 \mathrm{E}$ & 14 & 20 & 34 & 109 \\
\hline & (2) Hrazdan & $40.503493 \mathrm{~N} 44.748097 \mathrm{E}$ & 5 & 0 & 5 & \\
\hline & (3) Kuchak & $40.530503 \mathrm{~N} 44.284286 \mathrm{E}$ & 2 & 10 & 12 & \\
\hline & (4) Lchap & 40.467333 N $45.062083 \mathrm{E}$ & 2 & 11 & 13 & \\
\hline & (5) Noratus & $40.377694 \mathrm{~N} 45.211667 \mathrm{E}$ & 0 & 17 & 17 & \\
\hline & (6) Sevan & $40.564171 \mathrm{~N} 45.010575 \mathrm{E}$ & 3 & 0 & 3 & \\
\hline & (7) Tsovak & 40.179167 N $45.622972 \mathrm{E}$ & 15 & 10 & 25 & \\
\hline \multirow[t]{4}{*}{ D. valentini } & (8) Hatis (Geghama Mountains) & $40.304142 \mathrm{~N} 44.727975 \mathrm{E}$ & 0 & 4 & 4 & 17 \\
\hline & (3) Kuchak & $40.530503 \mathrm{~N} 44.284286 \mathrm{E}$ & 0 & 2 & 2 & \\
\hline & (9) Lchashen & 40.512756 N $44.900894 \mathrm{E}$ & 0 & 5 & 5 & \\
\hline & (10) Tezh (Pambak Ridge) & 40.702244 N $44.608556 \mathrm{E}$ & 0 & 6 & 6 & \\
\hline \multirow[t]{6}{*}{ D. raddei nairensis } & (11) Ayrivank & 40.433972 N $45.107556 \mathrm{E}$ & 0 & 2 & 2 & 45 \\
\hline & (12) Bjni & 40.461833 N $44.652056 \mathrm{E}$ & 0 & 1 & 1 & \\
\hline & (9) Lchashen & 40.512756 N $44.900894 \mathrm{E}$ & 0 & 14 & 14 & \\
\hline & (13) Pyunik (Pambak Ridge) & $40.613861 \mathrm{~N} 44.585111 \mathrm{E}$ & 0 & 17 & 17 & \\
\hline & (4) Lchap & 40.467333 N $45.062083 \mathrm{E}$ & 0 & 5 & 5 & \\
\hline & (14) Yerevan & $40.176944 \mathrm{~N} 44.602583 \mathrm{E}$ & 0 & 6 & 6 & \\
\hline
\end{tabular}

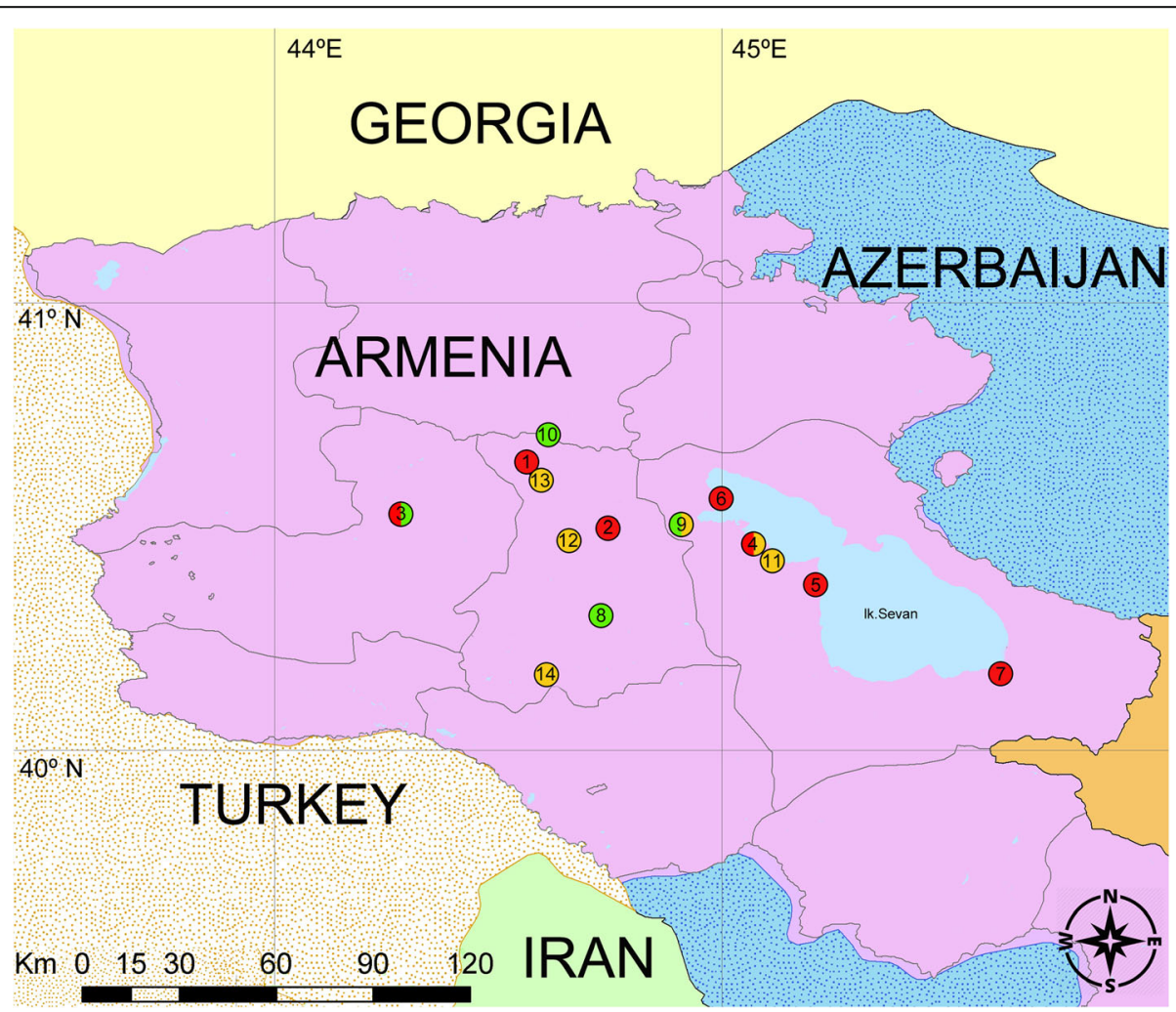

Fig. 3 Collection localities of parthenogenetic Darevskia unisexualis (shown in red) and their paternal species D. valentini (green) and maternal D. raddei nairensis (yellow). Numbers indicate populations: 1 - Artavaz (Hankavan); 2 - Hrazdan; 3 - Kuchak; 4 - Lchap; 5 - Noratus; 6 - Sevan; 7 Tsovak; 8 - Hatis (Geghama Mountains); 9 - Lchashen; 10 - Tezh (Pambak Ridge); 11 - Ayrivank; 12 - Bjni; 13 - Pyunik (Pambak Ridge); and 14 Yerevan. A licensed version ArcGIS Desktop 10.4 .1 (http://desktop.arcgis.com) was used to create the map 
Table 4 Coding matrix for the TCS network of alleles for D. unisexualis

\begin{tabular}{|c|c|c|c|c|c|c|c|c|c|c|}
\hline \multirow[t]{2}{*}{ Clone } & \multicolumn{4}{|l|}{ Locus } & \multicolumn{6}{|c|}{ Polymorphic Concatenated Sequence Sites } \\
\hline & Du215 & Du281 & Du323 & Du47G & 1 & 2 & 3 & 4 & 5 & 6 \\
\hline 1 & $4 \mathrm{~A} / 9 \mathrm{~A}$ & $10 \mathrm{~A} / 9 \mathrm{~A}$ & $7 \mathrm{~A} / 2 \mathrm{~A}$ & $5 \mathrm{~A} / 3 \mathrm{~A}$ & - & A & - & - & - & - \\
\hline 2 & $4 \mathrm{~A} / 10 \mathrm{~A}$ & $9 \mathrm{~A} / 9 \mathrm{~A}$ & $7 \mathrm{~A} / 2 \mathrm{~A}$ & $5 \mathrm{~A} / 3 \mathrm{~A}$ & A & - & - & - & - & - \\
\hline 3 & $4 \mathrm{~A} / 9 \mathrm{~A}$ & $10 \mathrm{~A} / 10 \mathrm{~A}$ & $7 \mathrm{~A} / 2 \mathrm{~A}$ & $5 \mathrm{~A} / 3 \mathrm{~A}$ & - & A & - & - & A & - \\
\hline 4 & $4 \mathrm{~A} / 9 \mathrm{~A}$ & $12 \mathrm{~A} / 9 \mathrm{~A}$ & $7 \mathrm{~A} / 2 \mathrm{~A}$ & $5 \mathrm{~A} / 3 \mathrm{~A}$ & - & A & A & A & - & - \\
\hline 5 & $4 \mathrm{~A} / 10 \mathrm{~A}$ & $10 \mathrm{~A} / 9 \mathrm{~A}$ & $7 \mathrm{~A} / 2 \mathrm{~A}$ & $5 \mathrm{~A} / 3 \mathrm{~A}$ & A & A & - & - & - & - \\
\hline 6 & $4 \mathrm{~A} / 9 \mathrm{~A}$ & $10 \mathrm{~A} / 9 \mathrm{~A}$ & $7 \mathrm{~A} / 2 \mathrm{~A}$ & $5 \mathrm{~A} / 4 \mathrm{~A}$ & - & A & - & - & - & A \\
\hline 7 & $4 \mathrm{~A} / 9 \mathrm{~A}$ & $9 \mathrm{~A} / 10 \mathrm{~A}$ & $7 \mathrm{~A} / 2 \mathrm{~A}$ & $5 \mathrm{~A} / 3 \mathrm{~A}$ & - & - & - & - & A & - \\
\hline 8 & $4 \mathrm{~A} / 10 \mathrm{~A}$ & $9 \mathrm{~A} / 9 \mathrm{~A}$ & $7 \mathrm{~A} / 2 \mathrm{~A}$ & $5 \mathrm{~A} / 4 \mathrm{~A}$ & A & - & - & - & - & A \\
\hline 9 & $4 \mathrm{~A} / 9 \mathrm{~A}$ & $9 \mathrm{~A} / 9 \mathrm{~A}$ & $7 \mathrm{~A} / 2 \mathrm{~A}$ & $5 \mathrm{~A} / 3 \mathrm{~A}$ & - & - & - & - & - & - \\
\hline 10 & $4 \mathrm{~A} / 9 \mathrm{~A}$ & $10 \mathrm{~A} / 10 \mathrm{~A}$ & $7 \mathrm{~A} / 2 \mathrm{~A}$ & $5 \mathrm{~A} / 4 \mathrm{~A}$ & - & A & - & - & A & A \\
\hline 11 & $4 \mathrm{~A} / 9 \mathrm{~A}$ & $11 \mathrm{~A} / 9 \mathrm{~A}$ & $7 \mathrm{~A} / 2 \mathrm{~A}$ & $5 \mathrm{~A} / 3 \mathrm{~A}$ & - & A & A & - & - & - \\
\hline 12 & $4 \mathrm{~A} / 9 \mathrm{~A}$ & $12 \mathrm{~A} / 9 \mathrm{~A}$ & $7 \mathrm{~A} / 2 \mathrm{~A}$ & $5 \mathrm{~A} / 4 \mathrm{~A}$ & - & A & A & A & - & A \\
\hline GATA- Link Variability & $4 / 9,10$ & $9-12 / 9,10$ & $7 / 2$ & $5 / 3,4$ & & & & & & \\
\hline
\end{tabular}

well as eight specimens of matrilineal ancestor $D$. raddei nairensis from six populations (1-2 individuals from each population). CYTB was chosen because it was used previously for the same species comparisons $[6,56]$. PCR and sequence data were generated as using primers L14841 (5'-CCATCCAACATCTCAGCATGATGAAA-3') and H15149 (5' -GCCCCTCAGAATGATATTTGTCCTCA$\left.3^{\prime}\right)[6,57]$. Amplification followed previous research [55]. An Applied Biosystems 3730 DNA Analyzer was used, and data were aligned using BioEdit v.7.0 [58].

\section{Supplementary information}

Supplementary information accompanies this paper at https://doi.org/10. $1186 / s 12864-020-6759-x$

Additional file 1: Table S1. Allelic variation of microsatellite containing loci in Darevskia unisexualis, D. valentini, and D. raddei nairensis.

Additional file 2: Table S2. Population indices of gene diversity for four loci in four sampled populations of $D$. raddei nairensis.

Additional file 3: Table S3. Population indices of gene diversity for four loci in four sampled populations of $D$. valentini.

\section{Abbreviations}

bp: Base pair; C (with number): Clone (number); CYTB: Mitochondrial gene encoding cytochrome b; DNA: Deoxyribonucleic acid; $\mathrm{H}_{\mathrm{E}}$ : Expected heterozygosity; $\mathrm{H}_{\mathrm{O}}$ : Observed heterozygosity; IUCN: International Union for Conservation of Nature's Red List; mtDNA: Mitochondrial DNA; N : Number of individuals or of alleles; P: Probability; PCR: Polymerase chain reaction; $R_{S}$ : Allelic richness; SE : Standard error; SNP: Single nucleotide polymorphisms; TCS: Tata Consultancy Services; TE buffer : Tris and EDTA buffer

\section{Acknowledgments}

Andrei Guliaev assisted the calculation of genetic indices, and Fedor Osipov helped prepare the manuscript.

\section{Authors' contributions}

APR: Conceptualization. AAV, and APR: Methodology. SKS: Software. AAV, FDD, and MSA: Validation. SKS: Formal analyses. AEG, AAV, and VIK: Investigation. APR: Resources. AAV, AEG, and VIK: Data curation. APR: Original draft. RWM, APR, and MSA: Writing, review \& editing. APR, AEG, RWM, and AAV: Visualization. RWM, APR, FDD, and MSA: Supervision. APR: Project administration. APR: Funding acquisition. All authors read and approved the final manuscript.

\section{Funding}

This research was funded by Russian Science Foundation (RSF) Research Project № 19-14-00083. This funding supported the experimental work, data analyses, and preparation of the manuscript. We thank the Russian Foundation for Basic Research, project № 17-00-00430 (17-00-00426) for funding fieldwork and some DNA sequencing of $D$. unisexualis and $D$. valentini. The work was conducted on the base of the Center for Collective Use, Institute of Gene Biology, Russian Academy of Sciences (GK02.451.11.7060). The funding bodies played no role in the design of the study and collection, analysis, and interpretation of data and in writing the manuscript.

\section{Availability of data and materials}

All data generated or analyzed during this study are included in this published article and its supplementary information files. All unique de novo sequences were deposited in GenBank (KX258628-KX258641; GU972551; KM573739; KM573746; KM573717-KM573727; KM573749-KM573751; KM573753; KM573755-KM573759; KM573761-M573762; HM014002HM014003; MH187990-MH187999; MN072617). Comparative data downloaded from GenBank for D. valentini had accession numbers GU972551, KM573717-KM573727, and MH187990-MH187999. The D. raddei nairensis cytochrome b gene dataset was obtained from NCBI Genbank, deposited under the accession number U88613.

\section{Ethics approval and consent to participate}

Our study relied mostly on previously collected samples. Thus, permission to collect the DNA samples used in this study was not required. We used tailtips of lizards preserved as museum specimens at Yerevan State University, which were collected in 2001-2005 with capture permit Code 5/22.1/51043 issued by the Ministry of Nature Protection of the Republic of Armenia for scientific studies. We also used blood samples of lizards, collected in 2018 and then these lizards were released in the site of collection, which precluded needing a collecting permit. Sampling was approved by the ethical guidelines of Yerevan State University and did not harm the lizards. The study was carried out in strict accordance with the guidelines and scientific standards. The study was approved by the Ethics Committee of Moscow State University (Permit Number: 24-01) and was carried out in strict accordance with their ethical principles and scientific standards. 


\section{Consent for publication}

Not applicable.

\section{Competing interests}

The authors declare that they have no competing interests.

\section{Author details}

'Laboratory of Genome Organization, Institute of Gene Biology of the Russian Academy of Sciences, Vavilova Str., 34/5, Moscow 119334, Russia. ${ }^{2}$ Department of Biochemistry, Molecular Biology and Genetics, Moscow State Pedagogical University, M. Pirogovskaya Str., 1/1, Moscow 119991, Russia. ${ }^{3}$ Faculty of Biology, Yerevan State University, 1 Alex Manoogian, 0025 Yerevan, Armenia. ${ }^{4}$ Department of Natural History, Royal Ontario Museum, 100 Queen's Park, Toronto, ON M5S 2C6, Canada.

\section{Received: 26 November 2019 Accepted: 28 April 2020}

\section{Published online: 11 May 2020}

\section{References}

1. Vrijenhoek RC, Dawley RM, Cole CJ, Bogart JP. A list of known unisexual vertebrates. In: Dawley RM, Bogart JP, editors. Evolution and Ecology of Unisexual Vertebrates, vol. 466. Albany: State Museum Bulletin; 1989. p. 19 23.

2. Neaves WB, Baumann P. Unisexual reproduction among vertebrates. Trends Genet. 2011:27:81-8.

3. Avise JC. Clonality: the genetics, ecology and evolution of sexual abstinence in vertebrate animals. Oxford: Oxford University Press; 2008.

4. Hedges SB, Marion AB, Lipp KM, Marin J, Vidal N. A taxonomic framework for typhlopid snakes from the Caribbean and other regions (Reptilia, Squamata). Caribb Herpetol. 2014:49:1-61.

5. Booth W, Schuett GW. The emerging phylogenetic pattern of parthenogenesis in snakes. Biol J Linn Soc Lond. 2016;118:172-86.

6. Darevsky IS. Rock lizards of the Caucasus: systematics, ecology and phylogenesis of the polymorphic groups of Caucasian rock lizards of the subgenus Archaeolacerta. Leningrad: Nauka; 1967. [in Russian: English translation published by Indian Natl Sci Doc Ctr, New Delhi, 1978].

7. Uzzell TM, Darevsky IS. Biochemical evidence for the hybrid origin of the parthenogenetic species of the Lacerta saxicola complex (Sauria, Lacertidae), with a discussion of some ecological and evolutionary implications. Copeia. 1975;1975:204-22.

8. Darevsky IS, Kupriyanova LA, Uzzell T. Parthenogenesis in reptiles. In: Gans C, Billett DF, editors. Biology of Reptilia, Vol. 15. New York: John Wiley \& Sons; 1985. p. 413-526.

9. Murphy RW, Fu J, MacCulloch RD, Darevsky IS, Kupriyanova LA. A fine line between sex and unisexuality: the phylogenetic constraints on parthenogenesis in lacertid lizards. Zool J Linnean Soc. 2000;130:527-49.

10. Reeder TW, Cole CJ, Dessauer HC. Phylogenetic relationships of whiptail lizards of the genus Cnemidophorus (Squamata: Teiidae): a test of monophyly, reevaluation of karyotypic evolution, and review of hybrid origins. Am Mus Novit. 2002;3365:1-61.

11. Darevsky IS. Natural parthenogenesis in certain subspecies of rock lizard, Lacerta saxicola. Dok Acad Nauk S.S.A.R. 1958;122:730-2 [in Russian: English translation published by Am Inst Biol Sci. 1958;1958:877-879].

12. Fujita MK, Moritz C. Origin and evolution of parthenogenetic genomes in lizards: current state and future directions. Cytogenet Genome Res. 2009; 127:261-72.

13. Manriquez-Moran NL, Cruz FR, Murphy RW. Genetic variation and origin of parthenogenesis in the Aspidoscelis cozumela complex: evidence from mitochondrial genes. Zool Sci. 2014;31:14-9.

14. Jancuchova-Laskova J, Landova E, Frynta D. Are genetically distinct lizard species able to hybridize? A review. Curr Zool. 2015;61:155-80.

15. Abdala CS, Baldo D, Juárez RA, Espinoza RE. The first parthenogenetic pleurodont iguanian: a new all-female Liolaemus (Squamata: Liolaemidae) from western Argentina. Copeia. 2016;2016:487-97.

16. Deakin J, Edwards MJ, Patel H, O'Meally D, Lian J, Stenhouse R, et al. Anchoring genome sequence to chromosomes of the central bearded dragon (Pogona vitticeps) enables reconstruction of ancestral squamate macrochromosomes and identifies sequence content of the $Z$ chromosome. BMC Genomics. 2016. https://doi.org/10.1186/s12864-0162774-3.
17. Simon JC, Delmotte F, Rispe C, Crease T. Phylogenetic relationships between parthenogens and their sexual relatives: the possible routes to parthenogenesis in animals. Biol J Linn Soc Lond. 2003;79:151-63.

18. Lutes AA, Neaves WB, Baumann DP, Wiegraebe W, Baumann P. Sister chromosome pairing maintains heterozygosity in parthenogenetic lizards. Nature. 2010:464:283-6.

19. Newton AA, Schnittker RR, Yu Z, Munday SS, Baumann DP, Neaves WB, et al. Widespread failure to complete meiosis does not impair fecundity in parthenogenetic whiptail lizards. Development. 2016;143:4486-94.

20. Parker ED. Ecological implications of clonal diversity in parthenogenetic morphospecies. Am Zool. 1979;19:753-62

21. Cole CJ, Dessauer HC, Barrowclough GF. Hybrid origin of a unisexual species of whiptail lizard, Cnemidophorus neomexicanus, in western North America: new evidence and a review. Am Mus Novit. 1988;2905:1-38.

22. Moritz C, Donnelan S, Adams M, Baverstock PR. The origin and evolution of parthenogenesis in Heteronotia binoei (Gekkonidae): extensive genotypic diversity among parthenogens. Evolution. 1989:43:994-1003.

23. Dessauer HC, Cole CJ. Diversity between and within nominal forms of unisexual teiid lizards. In: Dawley RM, Bogart JP, editors. Evolution and Ecology of Unisexual Vertebrates, vol. 466. Albany: State Museum Bulletin; 1989. p. 49-71.

24. Parker ED, Walker JM, Paulissen MA. Clonal diversity in Cnemidophorus: ecological and morphological consequences. In: Dawley RM, Bogart JP, editors. Evolution and Ecology of Unisexual Vertebrates, vol. 466. Albany: New York State Museum Bulletin; 1989. p. 72-6.

25. Moritz C, Uzzel T, Spolsky C, Hotz H, Darevsky IS, Kupriyanova LA, et al. The maternal ancestry and approximate age of parthenogenetic species of Caucasian rock lizards (Lacerta: Lacertidae). Genetica. 1992;87:53-62.

26. Fu J, MacCulloch RD, Murphy RW, Darevsky IS, Kupriyanova LA, Danielyan FD. The parthenogenetic rock lizard Lacerta unisexualis: an example of limited genetic polymorphism. J Mol Evol. 1998;46:127-30.

27. Janko K, Drozd P, Flegr J, Pannell JR. Clonal turnover versus clonal decay: a null model for observed patterns of asexual longevity, diversity and distribution. Evolution. 2008:62:1264-70.

28. Vrijenhoek RC. Factors affecting clonal diversity and coexistence. Am Zool. 1979;19:787-97.

29. Kearney M, Blacket MJ. The evolution of sexual and parthenogenetic Warramaba: a window onto Plio-Pleistocene diversification processes in an arid biome. Mol Ecol. 2008;17:5257-75.

30. The IUCN Red List. United Kingdom, Cambridge. 2019. https://www. iucnredlist.org. Accessed 26 Dec 2019.

31. Arakelyan MS, Danielyan FD, Corti C, Sindaco R, Leviton AE. Herpetofauna of Armenia and Nagoro-Karabakh. Salt Lake City: Society for Study of Amphibians and Reptiles; 2011.

32. Grechko W, Bannikova AA, Kosushkin SA, Ryabinina NL, Milto KD, Darevsky IS, et al. Molecular genetic diversification of the lizard complex Darevskia raddei (Sauria: Lacertidae): early stages of speciation. Mol Biol. 2007;41:76475.

33. Omelchenko AV, Girnyk AE, Osipov FA, Vergun AA, Petrosyan VG, Danielyan FD, et al. Genetic differentiation of natural populations of lizard complex Darevskia raddei, determined based on genome microsatellite markers. Russ J Genet. 2016;52:231-5.

34. Freitas S, Rocha S, Campos J, Ahmadzadeh F, Corti C, Sillero N, et al, Parthenogenesis through the ice ages: a biogeographic analysis of Caucasian rock lizards (genus Darevskia). Mol Phylogenet Evol. 2016;102: 112-27.

35. MacCulloch RD, Fu J, Darevsky IS, Danielyan FD, Murphy RW. Allozyme variation in three closely related species of Caucasian rock lizards (Lacerta). Amphibia-Reptilia. 1995;16:331-40.

36. Bobyn ML, Darevsky IS, Kupriyanova LA, MacCulloch RD, Upton DE, Danielyan FD, et al. Allozyme variation in populations of Lacerta raddei and Lacerta nairensis (Sauria: Lacertidae) from Armenia. Amphibia-Reptilia. 1996; 17:232-46.

37. Vergun AA, Martirosyan IA, Semyenova SK, Omelchenko AV, Petrosyan VG, Lazebny $\mathrm{OE}$, et al. Clonal diversity and clone formation in the parthenogenetic Caucasian rock lizard Darevskia dahli. PLoS One. 2014. https://doi.org/10.1371/journal.pone.0091674.

38. Ryskov AP, Osipov FA, Omelchenko AV, Semyenova SK, Girnyk AE, Korchagin $\mathrm{Vl}$, et al. The origin of multiple clones in the parthenogenetic lizard species Darevskia rostombekowi. PLoS One. 2017. https://doi.org/10.1371/journal. pone.0185161. 
39. Girnyk AE, Vergun AA, Semyenova SK, Guliaev AS, Arakelyan MS, Danielyan FD, et al. Multiple interspecific hybridization and microsatellite mutations provide clonal diversity in the parthenogenetic rock lizard Darevskia armeniaca. BMC Genomics. 2018. https://doi.org/10.1186/s12864-018-5359-5.

40. Murphy RW, Darevsky IS, RD MC, Fu J, Kupriyanova LA, Upton DE, et al. Old age, multiple formations or genetic plasticity? Clonal diversity in the uniparental Caucasian rock lizard, Lacerta dahli. Genetica. 1997;101:125-30.

41. Murphy R, MacCulloch R, Fu J, Darevsky I. Genetic evidence for species status of some Caucasian rock lizards in the Darevskia saxicola group. Amphibia-Reptilia. 2000;21:169-76.

42. Moritz C, Brown WM, Densmore LD, Wright JW, Vyas D, Donnellan S, et al. Genetic diversity and the dynamics of hybrid parthenogenesis in Cnemidophorus (Teiidae) and Heteronotia (Gekkonidae). In: Dawley RM Bogart JP, editors. Evolution and Ecology of Unisexual Vertebrates, vol. 466. Albany: New York State Museum Bulletin; 1989. p. 87-112.

43. MacCulloch RD, Murphy RW, Kupriyanova LA, Darevsky IS. The Caucasian rock lizard Lacerta rostombekovi: a monoclonal parthenogenetic vertebrate. Biochem Syst Ecol. 1997;25:33-7.

44. Parker ED, Selander RK. Low clonal diversity in the parthenogenetic lizard Cnemidophorus neomexicanus (Sauria: Teiidae). Herpetologica. 1984;40:24552.

45. Fu J, Murphy RW, Darevsky IS. Limited genetic variation in Lacerta mixta and its parthenogenetic daughter species: evidence from cytochrome $b$ and ATPase 6 gene DNA sequences. Genetica. 1999;105:227-31.

46. Badaeva TN, Malysheva DN, Korchagin VI, Ryskov AP. Genetic variation and de novo mutations in the parthenogenetic Caucasian rock lizard Darevskia unisexualis. PLoS One. 2008. https://doi.org/10.1371/journal.pone.0002730.

47. Danielyan F, Arakelyan M, Stepanyan I. Hybrids of Darevskia valentini, D. armeniaca and D. unisexualis from a sympatric population in Armenia. Amphibia-Reptilia. 2008;29:487-504.

48. Danielyan F, Grigoryan A, Aslanyan A, Arakelyan M, Arzumanyan G. Gametogenesis in triploid hybrids Lacerta valentini $\times$ L. unisexualis. In: Dzhivanyan KA, editor. Proceedings of the Scientific Conference, Dedicated to 75th Anniversary of the Department of Zoology of YSU. Yerevan: Department of Zoology of Yerevan State University; 1999. p. 39-40. [in Russian].

49. Kong S, Sánchez-Pacheco SJ, Murphy RW. On the use of median-joining networks in evolutionary biology. Cladistics. 2016;32:691-9.

50. Korchagin VI, Badaeva TN, Tokarskaya ON, Martirosyan IA, Darevsky IS, Ryskov AP. Molecular characterization of allelic variants of (GATA) $n$ microsatellite loci in parthenogenetic lizards Darevskia unisexualis (Lacertidae). Gene. 2007;392:126-33.

51. Kamvar ZN, Tabima JF, Grünwald NJ. Poppr: an R package for genetic analysis of populations with clonal, partially clonal, and/or sexual reproduction. PeerJ. 2014. https://doi.org/10.7717/peerj.281.

52. Paradis E, Schliep K. ape 5.0: an environment for modern phylogenetics and evolutionary analyses in R. Bioinformatics. 2018;35:526-8.

53. Winter DJ. MMOD: an R library for the calculation of population differentiation statistics. Mol Ecol Resour. 2012;12:1158-60.

54. Tarkhnishvili D, Murtskhvaladze M, Anderson CL. Coincidence of genotypes at two loci in two parthenogenetic rock lizards: how backcrosses might trigger adaptive speciation. Biol J Linn Soc Lond. 2017;121:365-78.

55. Templeton AR, Crandall KA, Sing CF. A cladistic analysis of phenotypic associations with haplotypes inferred from restriction endonuclease mapping and DNA sequence data. III. Cladogram estimation. Genetics. 1992; 132:619-33.

56. Fu J, Murphy RW, Darevsky IS. Divergence of the cytochrome b gene in the Lacerta raddei complex and its parthenogenetic daughter species: evidence for recent multiple origins. Copeia. 2000;2000:432-40.

57. Kocher TD, Thomas WK, Meyer A, Edwards SV, Paabo S, Villablance FX, et al. Dynamics of mitochondrial DNA evolution in animals, amplification and sequencing with conserved primers. Proc Natl Acad Sci U S A. 1989;86: 6196-200.

58. Hall TA. BioEdit, a user-friendly biological sequence alignment editor and analysis program for windows 95/98/ NT. Nucleic Acids Symp Ser. 1999;41: 95-8.

\section{Publisher's Note}

Springer Nature remains neutral with regard to jurisdictional claims in published maps and institutional affiliations.

\section{Ready to submit your research? Choose BMC and benefit from:}

- fast, convenient online submission

- thorough peer review by experienced researchers in your field

- rapid publication on acceptance

- support for research data, including large and complex data types

- gold Open Access which fosters wider collaboration and increased citations

- maximum visibility for your research: over $100 \mathrm{M}$ website views per year

At $\mathrm{BMC}$, research is always in progress.

Learn more biomedcentral.com/submissions 